\title{
CHANGES OF LAND USE AND LAND COVER IN SMALL ISLANDS CASE STUDY: WEH-SABANG ISLAND, INDONESIA
}

\author{
Arif, A.A. ${ }^{1}$, Machdar,I. ${ }^{2}$, Azmeri. ${ }^{3}$, Achmad,A. ${ }^{4}$ \\ 1. Architectural Study Program, Faculty of Engineering, Syiah Kuala University, Banda Aceh 23111, \\ Indonesia \\ 2. Department of Chemistry, Faculty of Engineering, Syiah Kuala University, Banda Aceh 23111, \\ Indonesia \\ 3. Department of Civil Engineering,Faculty of Engineering Syiah Kuala University, Banda Aceh \\ 23111, Indonesia \\ 4. PWK Study Program, Faculty of Engineering, Syiah Kuala University, Banda Aceh 23111, \\ Indonesia \\ Jln. Teuku Nyak Arief Darussalam, Banda Aceh \\ *Email: azhar_aarif@unsyiah.ac.id
}

\begin{abstract}
ABSTRAK
Development will increase sporadic land use and tend to cause land degradation. This paper is intended to investigate the effects of land use and land cover processes on Weh-Sabang Island, Indonesia. The duration of LULC changes is analyzed using Google Earth images from 2008 to 2018. Through observations of satellite imagery detected protected area and green space area has been greatly reduced in area and transformed into built-in land which functions as a tourist area and urban built environment. Where as in the coastal areas the change from vacant land to land that was built has also become larger over the past ten years. The increase in land density since 2008 is due to the construction of tourist attractions in hilly areas to coastal areas around Weh-Sabang Island, and can cause changes in the morphology and typology of the city of Sabang. Through the method of calculating the Land Diversity Index, changes can be made in the number of areas that have changed in the period of the year being monitored. The coastal areas experience more land use changes than hilly areas, and through observations of LULC changes across Weh Island, it is expected that efforts will be made to control land use changes in areas that have directly experienced land degradation, and must consider environmental control efforts. As small island like that which happened on Weh-Sabang Island. The westernmost island of the Republic of Indonesia..
\end{abstract}

Keywords: land use change and land cover, morphology, built environment, Weh island.

\section{INTRODUCTION}

As cities develop along with the growth of community economic activities, the city of Sabang is currently experiencing economic development, especially in the downtown area and port area. The phenomenon of this change must be controlled through the urban area planning tool through the Sabang City Spatial Plan (RTRW) product and the Urban Spatial Planning (RDTRK) Plan for the Sukajaya District and Sukakarya Subdistrict, as well as the Building and Environmental Plan (RTBL) in the downtown area of Sabang.

Cities must always have a distinctive identity and character. Sabang is a port city that is very well known as a natural port on Pulau
Weh. If the spatial planning of the city of Sabang as a tourist city is done well, it will be accepted by the community because it gives a real contribution to the development of the quality of life of the community. However, how the public responds if the structuring of the central area of Sabang that has been visited by many foreign tourists so far is not as beautiful as in design photos and drawings, and even eliminates elements of the city spatial structure and spatial patterns that have been formed for a long time and have been included in the Qanun of City Planning Sabang -Weh Island (Sabang RTRW, 2012-2032). Spatial Planning has explained the function of space to obtain a safe, comfortable, productive and sustainable environment that must be achieved in every 
region of the Republic of Indonesia in accordance with the mandate of the 1945 Constitution, namely to prosper the lives of Indonesian people.

\section{OBJECT AND RESEARCH LOCATION}

Weh Island is geographically located between $95^{\circ} 13 \quad 02$ "and $95^{\circ} 22$ '36" East Longitude, and between $05^{\circ} 46$ '28 "and 05'28" 54North Latitude. Geographically, this region is the westernmost administrative region in Indonesia, and is directly adjacent to three neighboring countries, namely Malaysia, Thailand and India. The city of Sabang consists of five islands, namely Pulau Weh $(121 \mathrm{~km} 2)$, Rubiah Island $(0.357 \mathrm{~km} 2)$,

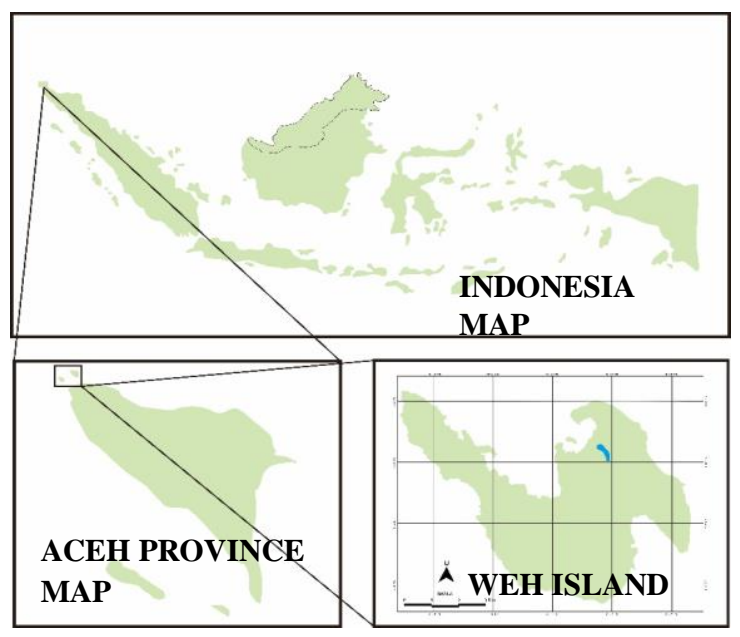

Figure 1. Map of the research area, WehSabang Island

Seulako Island $(0.055 \mathrm{~km} 2)$, Pulau Klah $(0.186 \mathrm{~km} 2)$, and Pulau Rondo $(0.650 \mathrm{~km} 2)$. The study focuses only on Weh Island from five islands in the Sabang City region given the fastest trading activities on the island. In addition, on Pulau Weh there is a freshwater lake called Danau Aneuk Laot which is the main source of clean water for people's lives, the tourism industry and the need for boats that pass and dock at the port of Sabang (Figure 1).

Weh Island is a volcanic island, a coral island where the process experiences elevation from the sea surface. The process takes place in three distinct stages from the presence of three terraces located at different heights. Weh Island consists of two types of rocks, namely tuf marina and core rock. Tuf marina is found almost along the coast to a height of 40 to 50 meters. The widest tuff layer is around the city of Sabang (RTRW of Sabang City, 2012-2032).

Small islands are defined by the Decree of the Minister of Marine Affairs and Fisheries No. 41/2000 Jo Minister of Maritime Affairs and Fisheries No. 67/2002 is an island with a size or equal to $10,000 \mathrm{~km} 2$, a population of less than 200,000 inhabitants (Table 1). The characteristics of small islands are ecologically separate from the main islands, have clear physical boundaries and are far from mainland island habitats, so they have high environmental value; cannot affect the hydrocarbon climate; has a relatively small catchment area so that most surface flows and sediments enter the sea. [4] Mujio, Adrianto, 2016; [8] Kurniawan, F, 2016; [9] Ika Kusumawati, 2014.

Table 1. comparison of changes in the spatial layout of the city of Sabang between 1900 and 2018 [10] Caecilia S. Wijayaputri, K. A. Arif (2014). The Concept of the Idea of Adaptation of Sabang City as a Built Environment.

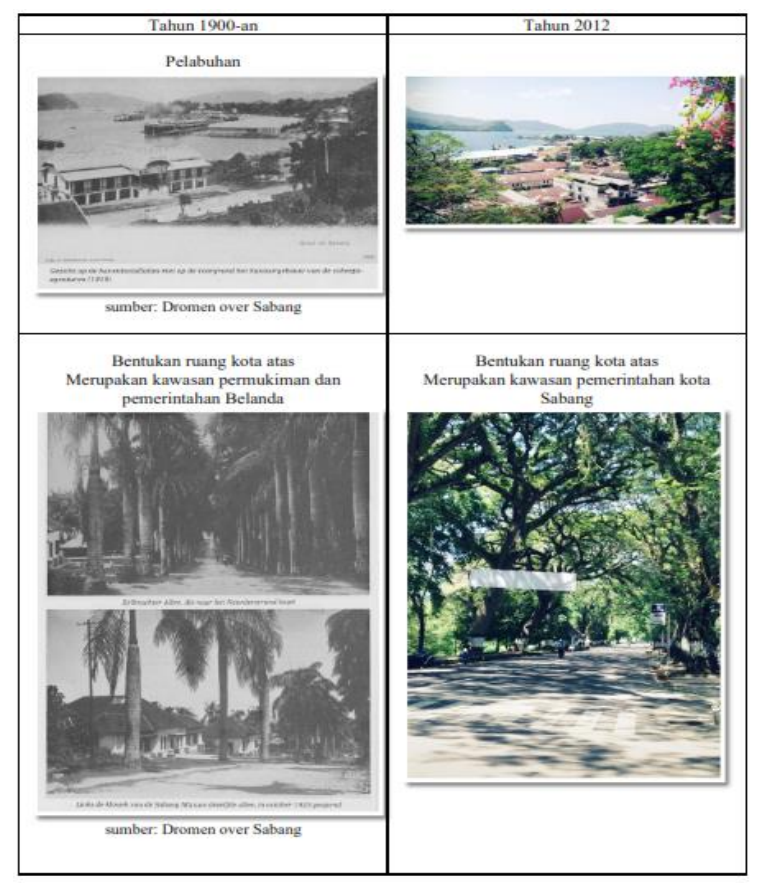

\section{RESEARCH METHODOLOGY AND DISCUSSION}

Existence of human activities in the subsystem of life will produce waste. Along 
with the rate of population growth and increasing demand for life, the production of waste produced by humans is estimated to increase from year to year. Garbage will cause many problems if not handled properly. As a city on a small island in Aceh Province, Weh island, which is located in the west of Indonesia, cannot be separated from the problem of garbage, especially solid waste.

Since its founding in the Netherlands in 1881, Sabang has functioned as a port city used for international shipping. Sabang was a Free Port and Free Trade Area in 1970, but was closed in 1985. Sabang is located in economic development in the South Asia region with the establishment of the Indonesia-MalaysiaThailand Growth Triangle Regional Economic Cooperation (IMT - GT) in 1993. After the establishment of Sabang as an Integrated Industrial Development Zone (KAPET) in 1998 and in 2000, the Government of the Republic of Indonesia issued Law No. 37 of 2000 concerning the Sabang Free Port and Free Trade Area, but has not experienced large activity. Then Sabang also experienced an earthquake and tsunami on December 26, 2004.

Sabang is also known as a unique natural and marine tourism area and as a zero kilometer from Indonesia. Increased population, local residents and migrants as well as an increase in the number of tourists visiting Sabang, has led to increased housing and food supply needs. The number of tourists who visit Sabang per year reaches 4 times the population of Sabang, where the population of Sabang is 30,653 people and the number of tourists to Sabang is as many as 121,466 people and 3,932 foreign tourists in 2010-2017. Meanwhile, to accommodate the number of tourist arrivals, there has been a surge in the number of housing and tourist facilities built sporadically by the public and investors. For this reason, we need to study the carrying capacity of the built environment of Weh Island - Sabang.

As an island, geographically Weh Sabang Island limits land and natural resources, so it is very dependent and requires a supply of raw materials and food ingredients from outside the island, especially the city of Banda Aceh. As is known that the UN-21 agenda suggests many challenges faced in planning and implementing sustainable development on an island, limited natural resources, also geographically isolated and highly dependent on other regions [1] PJ Deschenes, 2004.
Sustainable development of an island can be achieved by managing consumed resources and protecting ecosystems so as to minimize pollution. Changes in land use in a certain period can be analyzed by changes in land use and land cover (LULC). Analysis of land use change on Weh - Sabang Island was carried out using satellite imagery obtained from Google Earth, which is an independent software program that provides satellite imagery. This method also follows from what some previous researchers have done, including: [2] Izarul Machdar, et.al 2007; [5] Ashfa et.al 2016; [7] Mochamad Candra Wirawan Arief and Akemi Itaya 2017; [6] Azhar A Arif, 2018.

\section{Processing of clean water data on Weh Island - Sabang}

Bangunan di Kampung Kadu Ketug terdiri atas 4 jenis tipe bangunan, yaitu: 1) bangunan rumah ketua adat, 2) bangunan rumah warga (tipikal sama), 3) bangunan leuit, dan 4) bangunan jamban (fasilitas bersama).

Table 2. Clean water data on Pulau Weh - Sabang

\begin{tabular}{|c|c|c|}
\hline Year & $\begin{array}{c}\text { Number of Drinking } \\
\text { Water produced }\end{array}$ & $\begin{array}{c}\text { Number of } \\
\text { Customers }\end{array}$ \\
\hline 2015 & 1997414 & 5729 \\
\hline 2016 & 1404363 & 5668 \\
\hline 2017 & 1593597 & 5857 \\
\hline 2018 & 1726179 & 6176 \\
\hline
\end{tabular}

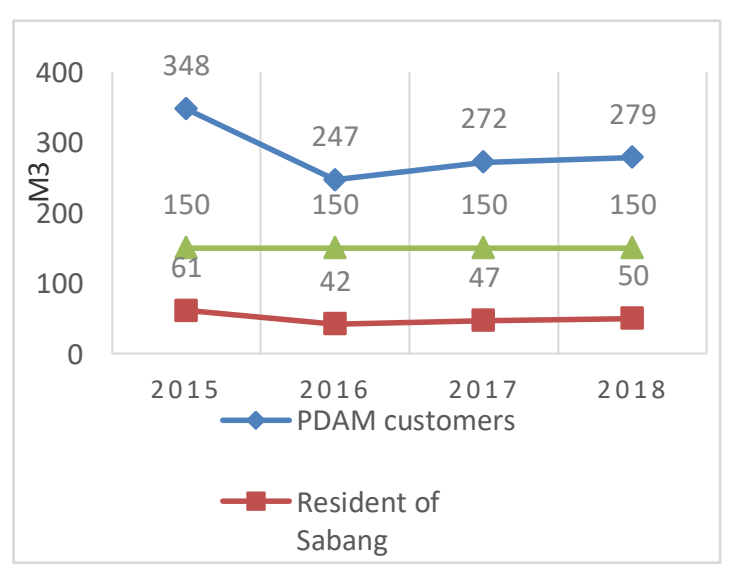


Tabel 3. Number of Villages, Population, Area and Population Density on Weh Island - Sabang

\begin{tabular}{|c|c|c|c|c|}
\hline No & Village & $\begin{array}{c}\text { Total } \\
\text { population }\end{array}$ & $\begin{array}{l}\text { Areas } \\
\left(\mathrm{Km}^{2}\right)\end{array}$ & $\begin{array}{c}\text { Population } \\
\text { Density } \\
\text { (people / } \\
\mathrm{Km}^{2} \text { ) } \\
\end{array}$ \\
\hline 1 & Iboh & 1053 & 273,116 & 4 \\
\hline 2 & $\begin{array}{l}\text { Batee } \\
\text { Shoek }\end{array}$ & 1091 & 112,951 & 10 \\
\hline 3 & $\begin{array}{c}\text { Paya } \\
\text { Seunara }\end{array}$ & 2453 & 56,322 & 44 \\
\hline 4 & $\begin{array}{c}\text { Krueng } \\
\text { Raya }\end{array}$ & 1507 & 95,927 & 16 \\
\hline 5 & $\begin{array}{c}\text { Aneuk } \\
\text { Laot }\end{array}$ & 1069 & 44,967 & 24 \\
\hline 6 & $\begin{array}{l}\text { Kuta } \\
\text { Timu }\end{array}$ & 2197 & 15,711 & 140 \\
\hline 7 & Kuta Barat & 3190 & 8,856 & 360 \\
\hline 8 & $\begin{array}{c}\text { Kuta } \\
\text { Ateuh }\end{array}$ & 4059 & 5,204 & 780 \\
\hline 9 & Paya & 547 & 14,4464 & 38 \\
\hline 10 & Keunekai & 819 & 5,6896 & 144 \\
\hline 11 & Beurawang & 386 & 4,6532 & 83 \\
\hline 12 & Jaboi & 644 & 4,9014 & 131 \\
\hline 13 & Balohan & 2821 & 7,776 & 363 \\
\hline 14 & $\begin{array}{c}\text { Cot } \\
\text { Abeuk }\end{array}$ & 543 & 3,5718 & 152 \\
\hline 15 & Cot Bak U & 5914 & 5,3109 & 1114 \\
\hline 16 & Anoi Itam & 661 & 10,1889 & 65 \\
\hline 17 & $\begin{array}{c}\text { Ujong } \\
\text { Kareung }\end{array}$ & 828 & 1,225 & 676 \\
\hline 18 & Ie Meulee & 3841 & 3,0689 & 1252 \\
\hline \multicolumn{2}{|r|}{ Total } & 33623 & 673,88611 & \\
\hline
\end{tabular}

Results of Analysis of BPS Sabang, Arif, AA (2018)

Table 4. The number of people who are not served by clean water in Weh Island

\begin{tabular}{|c|c|c|c|c|}
\hline Year & 2015 & 2016 & 2017 & 2018 \\
\hline $\begin{array}{c}\text { Amount of } \\
\text { Water (M3) }\end{array}$ & 1.997 .414 & 1.404 .363 & 1.593 .597 & 1.726 .179 \\
\hline $\begin{array}{c}\text { PDAM } \\
\text { customers }\end{array}$ & 5.729 & 5.668 & 5.857 & 6.176 \\
\hline $\begin{array}{c}\text { Total } \\
\text { Resident }\end{array}$ & 33.739 & 33.215 & 33.622 & 33.978 \\
\hline $\begin{array}{c}\text { Ideal } \\
\text { Amount } \\
\text { (150 } \\
\text { M3/people/ } \\
\text { day) }\end{array}$ & 13.316 & 9.362 & 10.623 & 11.507 \\
\hline $\begin{array}{c}\text { Amount not } \\
\text { get clean } \\
\text { water } \\
\text { services }\end{array}$ & 20.423 & 23.853 & 22.999 & 22.471 \\
\hline
\end{tabular}

Table 5. Land Use in the City of Sabang in 20022008

\begin{tabular}{llll}
\hline No. & Land Use & $(\mathrm{Ha})$ & $\%$ \\
\hline 1 & Forest & $8,229.92$ & 53,82 \\
& & & 2
\end{tabular}

\begin{tabular}{|c|c|c|}
\hline $\begin{array}{l}\text { Plantation / fields / } \\
\text { paddy fields }\end{array}$ & $4,943.35$ & $\begin{array}{l}32,32 \\
9\end{array}$ \\
\hline Lakes / ponds & 189.69 & 1,246 \\
\hline $\begin{array}{l}\text { Grasslands / open } \\
\text { fields }\end{array}$ & 944.28 & 6.18 \\
\hline Built Area & 798.32 & 5,22 \\
\hline $\begin{array}{l}\text { Special Areas (Ports } \\
\text { / Airports) }\end{array}$ & 185.13 & 1.21 \\
\hline Total & $15,290.68$ & 100 \\
\hline
\end{tabular}

Table 6. Land Use in the City of Sabang in 20082015

\begin{tabular}{llll}
\hline No. & Land Use & Area (Ha) & $\%$ \\
\hline 1 & Forest & $6,814.78$ & 41.7 \\
2 & Plantation / & $5,780.28$ & 37.8 \\
& $\begin{array}{l}\text { fields / paddy } \\
\text { fields }\end{array}$ & \\
3 & Lakes / ponds & 67.54 & 0.44 \\
4 & Grasslands / & $1,300.34$ & 8.5 \\
& open fields & & \\
5 & Built Area & $1,554.23$ & 10.1 \\
& special areas & 211.92 & 6 \\
6 & (Harbor / & & \\
& Airport) & & 1.38 \\
\hline & Total & $15,290.68$ & 100 \\
\hline
\end{tabular}

Source: BPS Data processing of Sabang City in 2008-2018, RTRW of Sabang City 2004-2014

Table 7. Land Use in Sabang City in 2015-2018

\begin{tabular}{llll}
\hline No. & Land use & Area & $\begin{array}{l}\text { (Ha) } \\
\%\end{array}$ \\
\hline 1 & Forest & $6,072.89$ & 39.7 \\
2 & Plantation / fields & $4,582.04$ & 29,9 \\
& / paddy fields & & 6 \\
3 & Lakes / ponds & 45,25 & 0,29 \\
4 & Grasslands / open & $1,752,1$ & 11.4 \\
& fields & $2,642.2$ & 5 \\
5 & Built Area & & 7 \\
& & 196.2 & 1,28 \\
6 & Special Areas & & \\
& (Ports / Airports) & & 100 \\
\hline & Total & $15,290.68$ &
\end{tabular}

Sources: Results of analysis of Google Earth 2018 [11] Azhar A. Arif, 2018. 


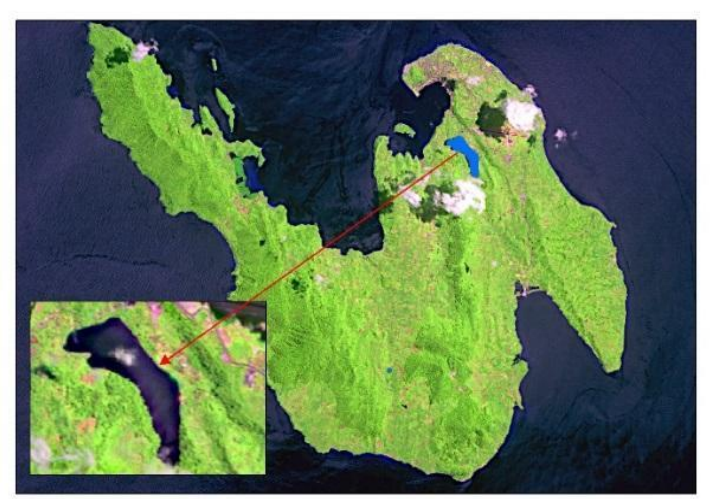

Figure 3. Raw water capacity on Aneuk Laot lake (2012)

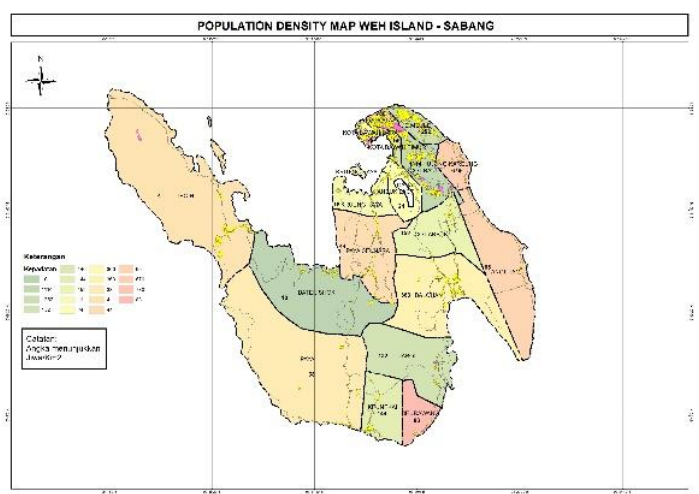

Figure 4. Population Density Map Weh Island Sabang ( 2012)

The most dominant changes in use land and land cover from 2008 to 2018 is an area that has increased by around $70 \%$ in the last five years, water bodies in Lake Aneuk Laot have decreased by $33 \%$ depreciation, agricultural land has decreased by $20 \%$ and forest area has decreased by $12 \%$ (Table 3,4,5,6 and 7 and Figure 3 and 4). Coverage of land around the lake has decreased, it will affect the condition of the availability of raw water in the lake. Based on the results of the LUC 2008-2018 analysis, the body area of water is rapidly decreasing (figure 5 and 6).

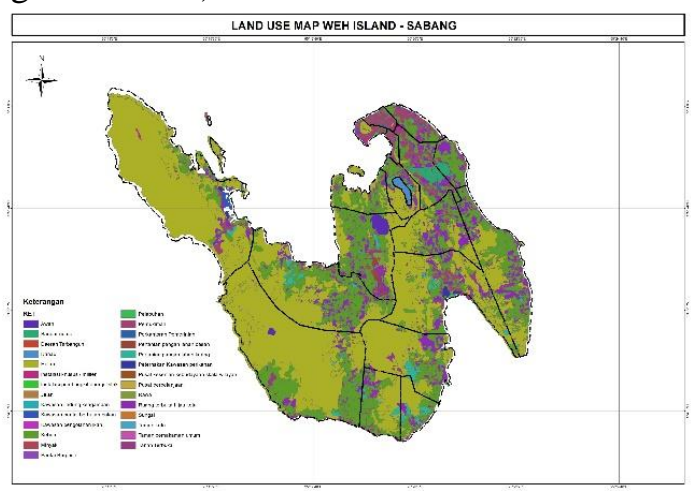

Figure 5. Land use Map Weh Island - Sabang (2012)

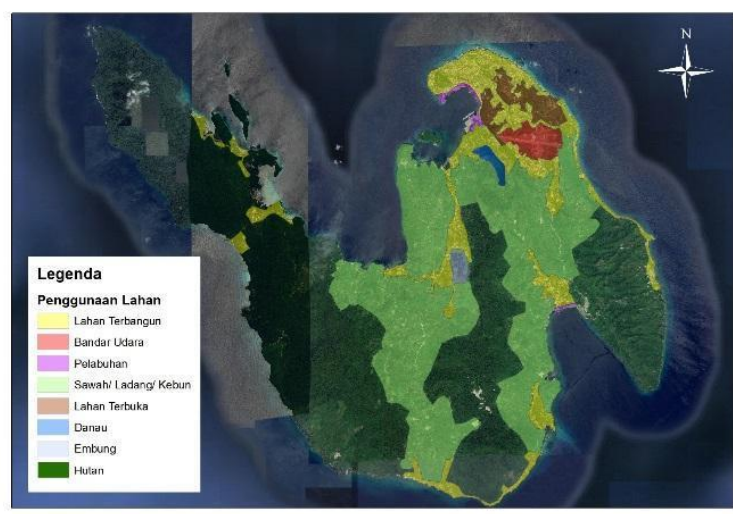

Figure 6. Land use series Google Earth satellite imagery (2018)

\section{CONCLUSION}

Research that will be carried out is expected to get an overview of development management on Weh island which contributes to protecting the environment of the island ecosystem itself and preserving the environment that is inherited to future generations. As mandated in Environmental Law No. 32 of 2009 in which one of the instruments to protect the environment was a spatial plan. What has been stated in the RTRW (Spatial Planning) product is the result of research to be able to become a concept of land use and consider the carrying capacity of the environment in the small island region

\section{Daftar Pustaka}

PJ Deschenes \& Marian Chertow (2004) Island Approach to Industrial Ecology: Towards Sustainability on Small Islands, Yale School of Forestry and Environmental Studies, New Haven, CT, USA. Journal of Environmental Planning and Management, 47(2), 201-217.

Machdar, Izarul, et al (2009) Research Proposal: Study of Water and Waste Problems and Potential Mitigation on Weh Island, Sabang. Unsyiah.

Arsana., I Made Andi (2016) Challenges and opportunities within Indonesia's maritime boundaries: legal and technical approaches. 
Mujio, Adrianto, L., Soewardi, K., \& Wardianto, Y. (2016) Analysis of potential conflicts in the use of coastal areas: integration of spatial plans. Rural Sociology, (Diposaptono).

Ashfa et al. (2017) (Research Presentation Poster): Implications of changes in land use / land cover and climate in ecosystem service values to support sustainable spatial planning on small islands. Unsyiah.

Arif, Azhar A (2018) Dissertation Research Proposal: Spatial Pattern Based on Environmental Carrying Capacity in Small Islands Case Study: Weh-Sabang Island. Unsyiah.

Arief , Mochamad Candra Wirawan \& Akemi Itaya (2018) Effect of the 2004 Indian Ocean Tsunami Recovery Process on Land Use and Land Cover in Banda Aceh, Indonesiaa, J. For. Plann, 22, 5561.

Kurniawan, F. et.al (2016) Patterns of landscape change on small islands: Case of Gili Matra Islands, Bahari Tourism Park, Indonesia. Procedia - Social and Behavioral Sciences .

Ika Kusumawati (2014). Key Factors for Management of the Sabang Marine Conservation Area.

Wijayaputri, Caecilia S. \& K. A. Arif (2014) The Concept of the Idea of Adaptation of Sabang City as a Built Environment, Institute for Research and Community Service - Parahyangan Catholic University

Arif,A.A., Machdar,I., Arifin,B., Achmad,A. (2018) Patterns of land use change base on environmental carrying capacity in small island : A case of Weh Island. IOP Conference Series Earth and environmental Science. 